\title{
PERSONAL SECURITY ACCOUNTS AND MANDATORY ANNUITIZATION IN A DYNASTIC FRAMEWORK
}

\author{
LUISA FUSTER \\ AYŞE İMROHOROĞLU \\ SELAHATTIN İMROHOROĞLU
}

CESIFO WORKING PAPER NO. 1405

CATEGORY 3: SOCIAL PROTECTION

FEBRUARY 2005

\footnotetext{
An electronic version of the paper may be downloaded

- from the SSRN website: Www.SSRN.com

- from the CESifo website: www.CESifo.de
} 


\title{
PERSONAL SECURITY ACCOUNTS AND MANDATORY ANNUITIZATION IN A DYNASTIC FRAMEWORK
}

\begin{abstract}
The aging of the populations in the OECD countries has prompted various calls for reforming the existing pay-as-you-go (PAYG) pension systems. Currently, there is renewed discussion in the United States about partial privatization where a fraction of the social security payroll tax would be diverted to Personal Security Accounts. In this paper, we quantitatively evaluate the welfare effects of reforming social security by introducing a PSA with and without mandatory annuitization in an economic environment with bequests and borrowing constraints. Our setup allows us to assess whether mandatory saving or mandatory annuitization of accumulated PSA wealth at retirement is welfare enhancing, and if so, for what type of individuals. Our setup follows Fuster, Imrohoroglu, and Imrohoroglu (2003) and studies various pension schemes in a two-sided altruistic framework where social security provides insurance against individual income and lifespan uncertainty. This framework is well suited to consider the annuity role of social security for single individuals versus for households where families also provide annuity insurance to their members.

Our main findings can be summarized as follows:

- A majority of households prefer a PSA reform (with or without mandatory annuitization) over the current PAYG pension system. Aggregate capital, output, and consumption, as well as individuals' lifetime welfare, are higher in the reformed pension system.

- Mandatory annuitization benefits most households.

In light of these findings, structuring the social security reform along a two-tiered system with a safety net for low income households that do not have access to family insurance, and allowing all households to accumulate retirement wealth faster through PSAs, and finally, requiring some level of annuitization of this wealth appear welfare improving for a large fraction of households.
\end{abstract}

JEL Code: E2, E6

Luisa Fuster

University of Toronto

150 St. George street

Toronto ON, M5S $3 G 7$

Canada

luisa.fuster@utoronto.ca
Ayse Imrohoroglu

University of Southern California

Los Angeles, California 90089-1427

USA

ayse@marshall.usc.edu

Selahattin Imrohoroglu

University of Southern California

Los Angeles, California 90089-1427

USA

selo@marshall.usc.edu

We would like to thank the participants of the Conference on Social Insurance in Munich, 5-6 November 2004. 


\section{Introduction}

The aging of the populations in the OECD countries has prompted various calls for reforming the existing pay-as-you-go (PAYG) pension systems. Almost all European Union countries are already implementing reforms to minimize the fiscal burden of the demographic shock on the individuals. Similar reform proposals are also being discussed for the United States economy. In 2001, a President's Commission to Strengthen Social Security was appointed to formulate proposals that would help maintain the current PAYG system's benefits for current retirees while improving the future pensions of current workers through 'personal security accounts'. The Commission proposed three plans. The first plan only recommended that workers make a voluntary contribution out of their social security payroll taxes into a Personal Security Account (PSA), owned and managed by the worker and invested in a well-diversified portfolio. The second plan extended this idea further and recommended diverting 4 percentage points of the social security payroll tax to PSAs while reducing the indexation of current pension by following price increases as opposed to wage increases. The third plan introduces a mix of add-on and carve-out approach such that a worker who chooses to voluntarily invest an additional 1 percent of earned income may divert 2.5

percent of social security payroll taxes, up to $\$ 1,000$ annually, to PSAs. Al- 
though plans 2 and 3 are clearly partial privatization plans, both plans also guarantee 30-year minimum-wage workers a retirement income above the poverty line. All 3 plans have the accounts owned by the participants and these accounts can be bequeathed to heirs.

The current debate on social security reform in the U.S. has therefore focused on the relative merits of the existing PAYG system versus some form of partial privatization with a safety net for low income workers. In its key features, the 2001 Commission's proposals are similar to the reform recommendations made by the 1997 Advisory Council on Social Security, according to which there were three approaches formulated to solve the long-term financial imbalance in the program: ${ }^{1}$

- Maintain Benefits: keep them essentially as is, but tax them.

- Individual Accounts: an additional and mandatory contribution of $1.6 \%$ of payroll.

- Personal Security Accounts: Convert the current system to a basic, flat benefit program, and $5 \%$ of the existing payroll tax redirected to PSAs.

\footnotetext{
${ }^{1}$ The organization of the 'Council' has since changed. Now there is a Social Security Advisory Board (SSAB), an independent, bipartisan board created by Congress and appointed by the President and the Congress to advise on matters related to the Social Security and Supplemental Security Inocme Programs. Its most recent report in 2003 suggest acting as soon as possible to reform the system.
} 
All these political efforts are attempts to change the current PAYG defined benefits program administered publicly into a two-tiered program with a first-tier flat basic pension financed in a PAYG manner, plus a privately managed defined contribution program. In the current defined benefit system, individuals are given insurance against life span risk as they receive retirement benefits as long as they are alive. On the other hand, a switch to a defined contribution retirement program can be designed to provide the same insurance if the funds in the individuals' accounts are required to be annuitized. However, as Diamond (1998) points out, political feasibility necessitates that the accounts' of the deceased be transferred to their estates. Clearly, setting the rules about the distribution of the accounts of workers who die before reaching retirement age is not a trivial task. ${ }^{2}$

A defined contribution plan must also specify rules about how the funds are withdrawn during retirement. There are several options: 1) the accumulations in PSAs are used to finance real annuities, 2) lump-sum withdrawals

\footnotetext{
${ }^{2}$ Boskin (1986) proposed a defined contribution plan where individuals' accounts are mandatorily annuitized. His suggestion was to separate retirement policies into two parts; the annuity part would provide actuarily equivalent insurance for retirement annuities, disability, and catastrophic hospital care, where as the welfare (or transfer) part would guarantee a minimally adequate level of retirement income to all citizens. Huggett and Ventura (1999) studied the steady-state effects of a Boskin type reform. Their treatment of the reform mimics the Boskin proposal and is quite different from the PSAs suggested above. First, the annuity part is financed in a PAYG basis. Second, benefits are set equal to the maximum of the floor benefit and the annuity part of the Boskin proposal. The floor benefit is proportional to output per worker, which is similar to the PSA reform. The social security tax rate that finances the annuity part is set equal to the actual U.S. social security tax rate.
} 
are made, or 3) a combination of the first two whereby phased withdrawals are made according to some formula and the remaining amount required to be annuitized. The Advisory Council in 1997 made two proposals for a defined contribution system that differed in the way that benefits are paid to individuals. On the one hand, the PSA proposal places no restriction on the form of benefit receipt. An intermediate position is the Chilean system where there is a limit in the size of monthly withdrawals for any part of the retirement account that is not annuitized.

As we mentioned above, Diamond (1998) argues that mandatory annuitization may not be the best option on how funds are withdrawn during retirement if individuals care about leaving bequests to their descendents. Regulation about how to withdraw funds during retirement is also not a trivial issue if the individuals face binding borrowing constraints. Clearly, establishing such rules are an integral part of the design mechanism for reforming social security.

In this paper, we quantitatively evaluate the welfare effects of reforming social security by introducing a PSA with and without mandatory annuitization in an economic environment with bequests and borrowing constraints. Our setup allows us to assess whether mandatory saving or mandatory annuitization of accumulated PSA wealth at retirement is welfare enhancing, 
and if so, for what type of individuals.

Our setup follows Fuster, İmrohoroğlu, and İmrohoroğlu (2003) and studies various pension schemes in a two-sided altruistic framework where social security provides insurance against individual income and lifespan uncertainty. The economy is populated by overlapping generations of individuals that differ in income and lifetime expectancy. The preferences are due to Laitner (1992) whereby individuals derive utility from their own lifetime consumption and from the felicity of their predecessors and descendents. In this framework, an unfunded social security system competes with family insurance to insure households members for the two types of risk mentioned above. The family insurance takes the form of intervivos transfers and bequests. Overall, the economy consists of a rich set of households. There are three general types of households depending on the number of surviving household members. Type 1 households have only the children surviving and the parents have died. Type 2 households have only the parents around and the children have not survived. Type 3 households constitute the majority and have both the parents and the children in the household. Amongst this type, we do have further heterogeneity. Since the parents and the children receive the realization of generationally-persistent 'ability' shocks, type 3 households are further divided into four ability combinations depending on 
the high-low ability realizations of the parents and the children.

This framework is well suited to consider the annuity role of social security for single individuals versus for households where families also provide annuity insurance to their members. Our goal is to quantitatively evaluate the proposed reforms along the lines of PSAs with or without mandatory annuitization of PSA wealth at retirement in this setup where some households have higher desire to annuitize wealth than others. We calibrate our economy to the U.S. economy, use numerical, discrete state-space methods to solve the households recursive decision problem, and restrict attention on steady-states under various pension system.

Our main findings can be summarized as follows:

- A majority of households prefer a PSA reform (with or without mandatory annuitization) over the current PAYG pension system. Aggregate capital, output, and consumption, as well as individuals' lifetime welfare, are higher in the reformed pension system.

- Mandatory annuitization benefits most households.

The paper is organized as followed. Section 2 presents the model in detail, Section 3 contains calibration. Numerical results are given in Section 4, and concluding remarks are presented in Section 5 . 


\section{The Model}

The economic environment in this paper follows Fuster, İmrohoroğlu, and İmrohoroğlu (2003). It is an applied general equilibrium model with overlapping generations facing lifespan and ability uncertainty, borrowing constraints, and exhibiting two-sided altruism. In order for the paper to be self-contained, we will describe the model although some of the details can be obtained in Fuster, İmrohoroğlu, and İmrohoroğlu (2003).

\subsection{Demographics and Endowments}

Our setup is a stationary overlapping generations model where every period $t$ a generation of individuals is born. Individuals face random lives and some live through the maximum possible age $2 T$. If the individuals survive, then his lifetime support overlaps during the first $T$ periods with the lifetime support of his father and during the last $T$ periods with the lifetime support of his children. The total population in the economy consists of $2 T$ overlapping generations of individuals with total measure one.

For each period, individuals are endowed with one unit of time which they supply inelastically to firms as labor hours. Uncertainty at the individual level is introduced by a random variable $z \in Z=\{H, L\}$ that determines lifetime labor ability; $z$ is a two-state, first-order Markov process with the 
transition probability matrix

$$
\Pi\left(z^{\prime}, z\right)=\left[\pi_{i j}\right], \quad i, j \in\{H, L\}
$$

where $\pi_{i j}=\operatorname{Pr}\left\{z^{\prime}=j \mid z=i\right\}, z$ is the labor ability of the father and $z^{\prime}$ is the labor ability of the new born in the dynasty .

The realization of the ability shock determines two features of an individual's lifetime opportunities. First, $z$ determines the individual's ageefficiency profile $\left\{\varepsilon_{j}(z)\right\}_{j=1}^{2 T}$. If $z=H$, the individual enjoys a permanently higher labor productivity throughout his life-span than an individual with $z=L$. Second, the realization of the labor ability shock determines an individual's life expectancy. We will use $\psi_{j}(z)$ to denote the probability of surviving to age $j+1$ conditional on having survived to age $j$ for an individual with ability $z$ for age $j=1,2, \ldots, 2 T$, where $\psi_{2 T}(z)=0$ and $z \in\{H, L\}$. In order to develop economic intuition about how the model works, it is important to note that there are no private insurance markets in the economy to diversify the risk of being born as a low ability-type individual. However, the informal family structure and some partial annuities, public or privately administered if they exist, do provide some partial insurance against this type of shock. 
Cohorts shares are time invariant due to our assumptions of constant conditional survival probabilities and population growth rate $n$. Using $\mu_{1}(z)=\lambda(z)(1+n)^{T}$ to indicate the size of cohort 1 (newborns) with ability $z$, relative to that of cohort $(T+1)$ (parents), where $(1+n)^{T}$ is the number of children per parent and $\lambda(z)$ is the measure of newborn individuals with ability $z$, we can obtain the relative sizes of the other generations recursively:

$$
\mu_{j+1}(z)=\frac{\psi_{j}(z) \mu_{j}(z)}{(1+n)}, \quad j=1, \ldots, 2 T-1
$$

\subsection{Technology}

There is a representative firm which rents capital, $K$, and hires labor, $N$, to produce a single good using a Cobb-Douglas production function $Y_{t}=$ $K_{t}^{\alpha}\left(A_{t} N_{t}\right)^{1-\alpha}$, where $\alpha \in(0,1)$ is the output share of capital, $Y_{t}$ is output

at time $t, K_{t}$ is aggregate capital input at time $t, N_{t}$ is aggregate labor input at time $t$, and $A_{t}$ is an exogenous labor-augmenting technological progress growing at a constant rate $\gamma$. Capital depreciates at a constant rate $\delta \in(0,1)$. Firms maximize profits so that factor prices are set equal to 
marginal products

$$
\begin{aligned}
\widetilde{r}_{t} & =\alpha K_{t}^{\alpha-1}\left(A_{t} N_{t}\right)^{1-\alpha}, \\
\omega_{t} & =(1-\alpha) K_{t}^{\alpha}\left(A_{t} N_{t}\right)^{-\alpha}
\end{aligned}
$$

where $\widetilde{r}_{t}$ is the rental price of capital and $\omega_{t}$ is the wage per effective labor.

\subsection{Social Security and Fiscal Policy}

\subsubsection{Personal Security Accounts without Annuitization}

Under a PSA system, retirement benefits come from two distinct sources. The first tier is a flat pension benefit equal to 18 percent of per capita GDP (a monthly payment of $\$ 410$ in 1996). This portion of the total benefit is financed in a pay-as-you-go fashion by taxing current labor income. Hence, the social security tax rate that finances the first-tier system is set such that its aggregate revenue equals the aggregate first-tier benefits:

$$
\sum_{z} \sum_{j=R}^{2 T} \mu_{j}(z) b=\tau_{s} \omega N
$$

where $b$ denotes the flat benefit, $\tau_{s}$ is the social security payroll tax to finance the first-tier benefits. We can obtain the following close form solution for the equilibrium tax rate by substituting $b=0.18 y$ and $y=\omega N /(1-\alpha)$ in 
the above equation:

$$
\tau_{s}=\frac{0.18}{1-\alpha} \sum_{z} \sum_{j=R}^{2 T} \mu_{j}(z) .
$$

The second tier of retirement benefits is financed by forced saving. Every period, the individual deposits 5 percent of earnings in PSAs. These funds are owned and managed by the individuals, invested in the capital market and therefore earns the rate of return on capital, and cannot be withdrawn until the individual retires. The capital income accumulated in the PSA is not taxed during the individual's working life. The amount of second tier benefits is determined by the wealth accumulated in these tax-favored personal security accounts. ${ }^{3}$ These assumptions define the following law of motion of the PSA (for an individual of ability $z$ )

$$
(1+\gamma) s_{j+1}(z)=(1+\widetilde{r}) s_{j}(z)+\kappa \omega \varepsilon_{j}(z)
$$

where $\kappa=0.05, s_{j+1}(z)$ denotes the PSA funds of an age- $j+1$ individual with ability $z$ and $s_{1}(z)=0$. At retirement the individual gets a lumpsum transfer of the wealth accumulated in his account which amounts to $(1+\widetilde{r}) s_{R}(z)$. If the individual does not survive to his retirement, his PSA

\footnotetext{
${ }^{3}$ We do not analyze whether these tax-favored accounts produce new saving. See İmrohoroğlu, İmrohoroğlu, and Joines (1998) for the impact of tax-favored Individual Retirement Accounts on saving in the United States.
} 
funds are transferred to his estate. Note that this reform is essentially a partial privatization achieved by a mandatory saving program.

\subsubsection{Personal Security Accounts with Mandatory Annuitization}

In a modified version of the above reform, we consider the case of partial privatization in which the funds accumulated in PSA are annuitized by the institution managing the PSAs. At retirement, individuals are entitled to an annuity payment, $b(z)$, which we assume to be proportional to the wealth accumulated in the PSA at retirement, that is, $b(z)=p(1+\widetilde{r}) s_{R}(z)$, where the proportion $p$ is determined endogenously as we explain below. The annuity payment remains constant during retirement, just like the first-tier flat PAYG benefit.

In order to compute the annuity payment of each individual, the social security system has to determine the proportion $p$ of accumulated wealth that the individual receives during retirement. This variable $p$ is set such that, the expected present value of the aggregate annuity payments of the generation that retires today equals the aggregate wealth held in PSA (the funds of individuals that are alive at retirement plus the funds of individuals that die before reaching retirement). ${ }^{4}$ The expected present value of the

\footnotetext{
${ }^{4}$ Notice that, $p$ is computed for the generation that retires in a given period and that
} 
aggregate annuity payments across individuals that retire today is given by

$$
\sum_{z} p(1+\widetilde{r}) s_{R}(z) \lambda(z) \sum_{j=R}^{2 T}\left(\frac{1+\gamma}{1+\widetilde{r}}\right)^{R-j} \prod_{i=1}^{j-1} \psi_{i}(z)
$$

the aggregate wealth accumulated in PSA by individuals, in this cohort, that survived to retirement, $\sum_{z}(1+\widetilde{r}) s_{R}(z) \lambda(z) \prod_{i=1}^{R-1} \psi_{i}(z)$ and the aggregate wealth of individuals who died before retirement is $\sum_{z}(1+\widetilde{r}) \sum_{j=2}^{R}\left(\frac{1+\widetilde{r}}{1+\gamma}\right)^{R-j} s_{j}(z) \lambda(z)(1-$ $\left.\psi_{j-1}(z)\right) \prod_{i=1}^{j-1} \psi_{i}(z)$. As a result, the proportion $p$ the defines the annuity payments must satisfy the following condition:

$$
p=\frac{\sum_{z}(1+\widetilde{r}) s_{R}(z) \lambda(z) \prod_{i=1}^{R-1} \psi_{i}(z)+\sum_{z}(1+\widetilde{r}) \sum_{j=2}^{R}\left(\frac{1+\widetilde{r}}{1+\gamma}\right)^{R-j} s_{j}(z) \lambda(z)\left(1-\psi_{j-1}(z)\right) \prod_{i=1}^{j-1} \psi_{i}(z)}{\sum_{z} p(1+\widetilde{r}) s_{R}(z) \lambda(z) \sum_{j=R}^{2 T}\left(\frac{1+\gamma}{1+\widetilde{r}}\right)^{R-j} \prod_{i=1}^{j-1} \psi_{i}(z)} .
$$

The above condition implies that the return of annuities is linked to the average mortality rate across individuals with differential mortality (high and low ability individuals) and, as a result, the return of annuities is not fair. This return could not be offered by private annuities since it would not be accepted by individuals with high mortality rate (low ability). In contrast, the government can provide this return because annuities are mandatory. we do not index $p$ by time because we are assuming a stationary equilibrium. 
In other words, the government can overcome an adverse selection problem (private information on differential mortality) in the annuity market because PSA are mandatory annuitized.

The law of motion of the aggregate wealth held in PSA by the social security system is

$$
(1+n)(1+\gamma) W_{t+1}=(1+\widetilde{r}) W_{t}+0.05 \omega N-B
$$

where $B=\sum_{z} \sum_{j=R}^{2 T} b(z)(1+\gamma)^{R-j} \mu_{j}(z)$ denotes the aggregate annuity payments at period $t$, if they were given the option. At each period $t$, the aggregate funds in PSA, $W_{t}$ are invested in the capital market.

\subsubsection{Government Budget}

In addition to the administration of the pension system, the government taxes labor income, capital income and consumption in order to finance exogenously given government purchases. We assume that the government's budget is balanced each period. Since tax rates and government expenditure are exogenous, the budget is balanced by an endogenous lump-sum transfer to the individuals. The government also collects the asset holdings and capital income of individuals that die without descendents. These resources 
are transferred in a lump-sum fashion to all survivors. ${ }^{5}$

\subsection{Preferences}

The preference structure in our setup follows Laitner (1992)'s two-sided altruistic specification in which individuals derive utility from their own lifetime consumption and from the felicity of their predecessors and descendants. This framework allows us to evaluate the annuity role of various social security institutions when families can also provide annuity insurance to their members. Furthermore, in this setup, strategic behavior between the father and the children does not arise because their decisions maximize the same objective function. Therefore, due to this commonality of interests during the periods when their lives overlap, the father and the children constitute a single decision unit by pooling their resources. We call this decision unit a 'household' which is constituted by an adult male, the father, of generation $j$ and age $T+1$, and his $m=(1+n)^{T}$ adult children of generation $j+T$ and age 1 . A household survives $T$ periods or until the father and the children have died. ${ }^{6}$ A dynasty consists of a sequence of

\footnotetext{
${ }^{5}$ In previous work, we have experimented with other distribution schemes for unintended bequests. Since the flow of these is only a small fraction of per person income, our quantitative results are robust to other schemes.

${ }^{6}$ We are assuming that, In a given household, all children are born at the same period and all of them die at the same period. Furthermore, we take all children in a given household to be identical regarding their labor abilities and vector of conditional survival probabilities.
} 
households that belong to the same family line. If the children survive to age $T+1$, each of them becomes a father in the 'next-generation household' of the same dynasty. Otherwise, the family line is broken, and this dynasty is over. Since the population experiences broken dynasties every period, we assume that these dynasties are replaced by new dynasties to maintain our assumption of a stationary demographic structure. Since mortality rates are higher for low ability individuals, the number of new dynasties of low ability is higher than the number of dynasties of high ability. A new dynasty begins with an individual of age 1 that holds zero assets.

Households are heterogeneous with respect to their asset holdings, age, abilities, and their composition. When the father or his $m$ children die, the household composition changes. Because we assume that the life-span shocks that affects each of the children are perfectly correlated, there are three types of households. Type- 1 households are those where the father has died. Type-2 households consist only of the father since the $m$ children have died. Households of type- 3 are those where both the father and the children are still alive.

The budget constraint facing an age- $j$ household, where $j=1,2, \ldots, T-$ 
1 is the age of the youngest member(s), is given by

$$
\begin{aligned}
{\left[\phi_{s}(h)+\phi_{f}(h)\right]\left(1+\tau_{c}\right) c_{j}+(1+\gamma) a_{j}=} & {\left[1+r\left(1-\tau_{k}\right)\right] a_{j-1} } \\
& +e_{j}\left(h, z, z^{\prime}\right)+\left[\phi_{s}(h)+\phi_{f}(h)\right]\left(\xi_{1}+\xi_{2}\right),
\end{aligned}
$$

where $\phi_{s}$ is an indicator function which takes the value $m$ if the children are alive and 0 otherwise, while $\phi_{f}$ is an indicator function that takes the value unity if the father is alive and 0 otherwise; $h \in\{1,2,3\}$ is an indicator of household composition, $r=\widetilde{r}-\delta, e_{j}\left(h, z, z^{\prime}\right)$ are the after tax earnings, $c_{j}$ is the consumption of each household member, $a_{j}$ denotes the asset holdings to be carried over to age $j+1, \xi_{1}$ is the lump sum redistribution of unintended bequests left behind by fathers without sons and confiscated by the government, $\xi_{2}$ is a lump sum transfer to balance the government's budget, and $\tau_{c}$ and $\tau_{k}$ denote the consumption and capital income tax rates, respectively. All per capita aggregate quantities reported in the paper are divided by the level of the technology, $A_{t}$, and therefore represented in efficiency units. As we restrict attention to steady-states, consumption, asset holdings, lump-sum transfers, and earnings are in efficiency units and constant over time.

We represent the net of tax earnings of an age- $j$ household with the 
function $e_{j}\left(h, z, z^{\prime}\right)$ :

$$
\begin{aligned}
& e_{j}\left(h, z, z^{\prime}\right) \\
& =\left\{\begin{array}{l}
\phi_{s}(h) \omega\left(1-\tau_{s}-\tau_{\ell}-\kappa\right) \varepsilon_{j}\left(z^{\prime}\right)+\phi_{f}(h) B_{j+T}(z) \text { if } j \geq R-T, \\
\phi_{s}(h) \omega\left(1-\tau_{s}-\tau_{\ell}-\kappa\right) \varepsilon_{j}\left(z^{\prime}\right)+\phi_{f}(h) \omega\left(1-\tau_{s}-\tau_{\ell}-\kappa\right) \varepsilon_{j+T}(z), \text { if not, }
\end{array}\right.
\end{aligned}
$$

where $\tau_{s}$ is the first-tier social security tax rate, $\tau_{\ell}$ is the personal tax rate on labor income, and $\kappa$ is the rate of mandatory saving. For the PAYG pension system, $B_{j+T}(z)$ denotes the pension at age $j+T$, which depends on average lifetime earnings calculated using the wage at the retirement period, that is, $\omega /(1+\gamma)^{j+T-R}$. For the PSA reform without annuitization, $B_{j+T}(z)=b$, and for the PSA reform with mandatory annuitization, $B_{j+T}(z)=b(z)$ as described in the previous section. Note that an individual's pension remains constant during retirement while technology grows at the rate $\gamma$. Thus the pension per effective labor decreases during retirement at rate $\gamma$, that is, $B_{j+T}(z)=B_{R}(z) /(1+\gamma)^{j+T-R}$. Put differently, the retirement benefits of successive cohorts increase at the rate $\gamma$. 
For $j=T$, the budget constraint of the household is given by

$$
\begin{aligned}
& {\left[\phi_{s}(h)+\phi_{f}(h)\right]\left(1+\tau_{c}\right) c_{T}+(1+n)^{T}(1+\gamma) a_{T} } \\
= & {\left[1+r\left(1-\tau_{k}\right)\right] a_{T-1}+e_{T}\left(h, z, z^{\prime}\right)+} \\
& {\left[\phi_{s}(h)+\phi_{f}(h)\right]\left(\xi_{1}+\xi_{2}\right) . }
\end{aligned}
$$

If the children survive to age $T,(1+n)^{T}$ new households are constituted in the dynasty and each of them will hold $a_{T}$ assets. If the children do not survive to age $T$, the family line breaks.

The above budget constraints are designed for the PAYG social security system, with the additional assumption of $\kappa=0$. To represent PSAs, we need to take $\kappa=0.05$, and add $(1+\widetilde{r}) s_{R}(z)$ to the right hand side of the budget for the first year of retirement, and also keep track of the accumulation of PSA wealth through equation (3).

It is assumed that households face borrowing constraints and cannot hold negative assets at any age:

$$
a_{j} \geq 0, \quad \forall j .
$$

Individuals obtain utility from their consumption and from their predecessors and descendents consumption. We restrict the utility function to 
the CRRA class because we assume a balanced growth path for our economy. We will use the language of recursive economic theory to describe the household's decision problem.

Let $V_{j}\left(a, h, z, z^{\prime}\right)$ denote the maximized value of expected, discounted lifetime utility of an age- $j$ household with the state vector $\left(a, h, z, z^{\prime}\right)$. For a household of age $j \leq T$,

$$
\begin{aligned}
& V_{j}\left(a, h, z, z^{\prime}\right) \\
= & \max _{\left\{c, a^{\prime}\right\}}\left\{\left[\phi_{s}(h)+\phi_{f}(h)\right] \frac{c^{1-\sigma}}{1-\sigma}+\beta(1+\gamma)^{1-\sigma} \widetilde{V}_{j+1}\left(a^{\prime}, h^{\prime}, z, z^{\prime}\right)\right\} \\
& \text { subject to (4)-(7), }
\end{aligned}
$$

where $\sigma$ is the coefficient of relative risk aversion and

$$
\widetilde{V}_{j+1}\left(a^{\prime}, h^{\prime}, z, z^{\prime}\right)= \begin{cases}\sum_{h^{\prime}=1}^{3} \chi_{j}\left(h, h^{\prime} ; z, z^{\prime}\right) V_{j+1}\left(a^{\prime}, h^{\prime}, z, z^{\prime}\right) & \text { for } j=1,2, \ldots, T-1, \\ \psi_{T}\left(z^{\prime}\right)(1+n)^{T} \sum_{z^{\prime \prime} \in\{H, L\}} \pi_{z^{\prime} z^{\prime \prime}} V_{1}\left(a^{\prime}, 3, z^{\prime}, z^{\prime \prime}\right) & \text { for } j=T,\end{cases}
$$

$\chi_{j}\left(h, h^{\prime} ; z, z^{\prime}\right)$ is the probability that a household of age $j$ and type $h$ becomes type $h^{\prime}$ the next period given that the father is of ability $z$ and the children of ability $z^{\prime}{ }^{7}$

\footnotetext{
${ }^{7}$ We describe the computation of the measures of households in detail in the appendix. For a description of the solution method see Fuster (1999).
} 


\subsection{Steady State Equilibrium}

A fiscal policy is a set $\left\{G, B, \tau_{\ell}, \tau_{k}, \tau_{c}, \tau_{s}, \kappa\right\}$. Given fiscal policy, a stationary recursive competitive equilibrium is a set of value functions $\left\{V_{j}\left(a, h, z, z^{\prime}\right)\right\}_{j=1}^{T}$, households' decision rules $\left\{c_{j}(\cdot), a_{j}(\cdot)\right\}_{j=1}^{T}$, time invariant measures of households $\left\{X_{j}\left(a, h, z, z^{\prime}\right)\right\}_{j=1}^{T}$, relative prices of labor and capital $\{\omega, r\}$, a lump sum distribution of unintended bequests $\xi_{1}$, and a lump-sum government transfer $\xi_{2}$ such that the following conditions are satisfied:

1. given fiscal policy, prices and lump-sum transfers, households' decision rules solve households' decision problem (8);

2. firms maximize profits, i.e. (1) and (2) hold;

3. aggregation holds,

$$
\begin{aligned}
\widetilde{K} & =\sum_{j, a, h, z, z^{\prime}} a_{j-1}\left(a, h, z, z^{\prime}\right) X_{j}\left(a, h, z, z^{\prime}\right)(1+n)^{1-j}+W \\
\widetilde{N} & =\sum_{j=1}^{R-1} \sum_{z \in\{H, L\}} \varepsilon_{j}(z) \mu_{j}(z), \\
C & =\sum_{j, a, h, z, z^{\prime}}\left[\phi_{s}(h)+\phi_{f}(h)\right] c_{j}\left(a, h, z, z^{\prime}\right) X_{j}\left(a, h, z, z^{\prime}\right)(1+n)^{1-j},
\end{aligned}
$$

where $W=\sum_{z} \sum_{j=1}^{R} s_{j}(z) \mu_{j}(z)$ is the aggregate PSA wealth in the economy, adjusted for growth; 
4. the set of age-dependent measures of households satisfies

$$
\begin{aligned}
& X_{j+1}\left(a^{\prime}, h^{\prime}, z, z^{\prime}\right) \\
= & \sum_{\left\{a, h: a^{\prime}=a_{j}\left(a, h, z, z^{\prime}\right)\right\}} X_{j}\left(a, h, z, z^{\prime}\right) \chi_{j}\left(h, h^{\prime} ; z, z^{\prime}\right), \text { for } j=1, \ldots, T-1 ;
\end{aligned}
$$

the invariant distribution of age- 1 households is given by conditions

$$
X_{1}\left(a^{\prime}, 3, z^{\prime}, z^{\prime \prime}\right)=\pi_{z^{\prime} z^{\prime \prime}} \sum_{\left\{a, h, z: a^{\prime}=a_{T}\left(a, h, z, z^{\prime}\right)\right\}} X_{T}\left(a, h, z, z^{\prime}\right) \chi_{T}\left(h, 3 ; z, z^{\prime}\right)
$$

and

$$
X_{1}\left(0,1, z^{\prime}, z^{\prime \prime}\right)=\lambda\left(z^{\prime}\right) \pi_{z^{\prime} z^{\prime \prime}}-\sum_{a^{\prime}} X_{1}\left(a^{\prime}, 3, z^{\prime}, z^{\prime \prime}\right)
$$

that is, new dynasties, holding zero assets, substitute for the family lines broken during any given period;

5. the lump-sum redistribution of unintended bequests satisfies

$$
\xi_{1}=(1+r) \sum_{j=1}^{T} a_{j}\left(a, h, z, z^{\prime}\right) X_{j}\left(a, h, z, z^{\prime}\right)\left[1-\sum_{h^{\prime}=1}^{3} \chi_{j}\left(h, h^{\prime} ; z, z^{\prime}\right)\right](1+n)^{1-j},
$$

6. the government's budget is balanced

$$
\xi_{2}=\tau_{k} r\left[\widetilde{K}-\frac{\xi_{1}}{1+r}\right]+\tau_{\ell} \omega \widetilde{N}+\tau_{c} C-G
$$


7. the first-tier social security tax rate is such that the budget of the social security system is balanced

$$
\sum_{j=R}^{2 T} \sum_{z=H, L} B_{j}(z) \mu_{j}(z)=\tau_{s} \omega \widetilde{N}
$$

8. the goods market clears

$$
C+[(1+n)(1+\gamma) \widetilde{K}-(1-\delta) \widetilde{K}]+G=\widetilde{K}^{\alpha} \widetilde{N}^{1-\alpha}
$$

\section{Calibration and Solution}

We are going to calibrate our model economy to the long run quantities in the U.S. economy in order to conduct our counterfactual experiments for reforming social security. Our main calibration target is the average capitaloutput ratio in the U.S. economy over the last fifty years, 2.5. Table 1 shows the major modeling and calibration choices made. 
Table 1: List of Parameters

\begin{tabular}{|c|c|c|c|}
\hline & & Population & \\
\hline $2 T$ & $=$ & 14 & Maximum lifetime (70 years) \\
\hline$R$ & $=$ & 10 & Retirement age (45 years) \\
\hline \multirow[t]{2}{*}{$n$} & $=$ & 0.012 & Population growth rate (annual) \\
\hline & & Utility & \\
\hline$\sigma$ & $=$ & 2 & Coefficient of relative risk aversion \\
\hline \multirow[t]{2}{*}{$\beta$} & $=$ & 0.988 & Annual discount factor \\
\hline & & Production & \\
\hline$\gamma$ & $=$ & 0.0165 & Annual rate of growth of technology \\
\hline$\alpha$ & $=$ & 0.31 & Capital share of GNP \\
\hline$\delta$ & $=$ & 0.044 & Annual depreciation rate \\
\hline$\lambda(H)$ & $=$ & 0.28 & Measure of individuals with high ability \\
\hline \multirow[t]{2}{*}{$\pi_{L L}=0.83$} & & $\pi_{H H}=0.57$ & Transition probability matrix of abilities \\
\hline & & Fiscal Policy & \\
\hline$\tau_{l}$ & $=$ & 0.2 & Labor income tax rate \\
\hline$\tau_{k}$ & $=$ & 0.4 & Capital income tax rate \\
\hline$\tau_{c}$ & $=$ & 0.05 & Consumption tax rate \\
\hline$G / Y$ & $=$ & $18 \%$ & Government expenditure to GDP ratio \\
\hline
\end{tabular}


A newborn in our setup is a 21 year old individual; a model period is five years. Retirement is mandatory at age 65, and maximum lifespan is 90 years. The population growth rate is $1.2 \%$ per year, and the productivity growth rate is $1.65 \%$ annually. Again, these are the averages from the U.S. economy over the last fifty years. The depreciation rate is taken as $4.4 \%$, and capital's share of GNP is $31 \%$.

Fiscal policy is captured by a constant annual government-GNP ratio of $18 \%$, and taxes on labor income, capital income, and consumption, at $20 \%$, $40 \%$, and $5 \%$, respectively.

The coefficient of relative risk aversion $\sigma$ is set equal to 2 , and the subjective discount factor $\beta$ is taken as 0.988 in order to obtain a capital-output ratio of $2.5 .^{8}$

\section{$4 \quad$ Numerical Findings}

\subsection{Aggregate Long Run Effects}

We summarize the long-run effects of various types of reform in Table 2 . The benchmark steady-state describes the current U.S. economy where pensions are provided by a PAYG system with a replacement rate of $44 \%$ and a payroll

\footnotetext{
${ }^{8}$ For details of the calibration choices, see Fuster, İmrohoroğlu, and İmrohoroğlu (2003).
} 
tax rate of $9.44 \%$. We set the values of aggregate variables in this steadystate equilibrium equal to 100 for easy comparison with other steady-state equilibria under alternative reform proposals.

Table 2: Aggregate Effects of Reforms

\begin{tabular}{ccccccc}
\hline \hline & $\tau$ & $\kappa$ & $K$ & $Y$ & $r\left(1-\tau_{k}\right)$ & $C$ \\
Benchmark & 0.0944 & 0 & 100.0 & 100.0 & 0.0462 & 100.0 \\
PSA+Annuity & 0.0438 & $5 \%$ & 109.5 & 102.8 & 0.0424 & 101.8 \\
PSA & 0.0438 & $5 \%$ & 108.9 & 102.7 & 0.0426 & 101.7 \\
Elimination & 0.0000 & 0 & 106.1 & 101.8 & 0.0437 & 101.2 \\
\hline \hline
\end{tabular}

The steady-state labeled 'Elimination' is an equilibrium where there is no unfunded system at all and all individuals are left free to save the optimal amounts desired to support old-age consumption. The steady-states labeled 'PSA+Annuity' and 'PSA' enforce mandatory saving at the rate of $5 \%$ of individuals' gross wage income in each of the years during their working life. Not surprisingly, all three alternative steady-states exhibit higher capital stock than the benchmark economy since the distortion on saving is reduced with the decline of the payroll tax from $9.44 \%$ to $4.38 \%$. Perhaps surprisingly, the steady-states with mandatory saving yield higher aggregate capital and consumption than the fully privatized equilibrium. This might be due to the fact that the combination of the two tiers for retirement con- 
sumption under the PSA reforms with mandatory saving programs yields a higher aggregate saving rate than the steady-state in which there is no social security system.

\subsection{Welfare Effects}

Table 3 shows the lifetime utility of newborn households for different composition and ability types. The first row describes the welfare of households at the benchmark steady-state. The second and third raws show the welfare levels under the partial privatization proposals, and the last row depicts the welfare of households under full privatization.

Table 3: Welfare of Newborns

\begin{tabular}{|c|c|c|c|c|c|c|c|c|}
\hline & \multicolumn{5}{|c|}{ Type 3} & \multicolumn{3}{|c|}{ Type 1} \\
\hline & $\tau_{s}$ & $\kappa$ & $\mathbf{H H}$ & HL & LH & $\mathbf{L L}$ & $\mathbf{H}$ & $\mathbf{L}$ \\
\hline Benchmark & 0.0944 & 0.00 & -48.66 & -56.13 & -55.72 & -66.85 & -46.89 & -59.03 \\
\hline PSA+Annuity & 0.0438 & 0.05 & -48.24 & -56.74 & -53.69 & -65.39 & -46.01 & -60.06 \\
\hline PSA & 0.0438 & 0.05 & -49.20 & -57.47 & -54.36 & -65.66 & -45.97 & -58.73 \\
\hline Elimination & 0.0000 & 0.00 & -49.02 & -57.25 & -54.78 & -66.62 & -44.39 & -55.66 \\
\hline \multicolumn{3}{|c|}{ Measure of types } & 0.147 & 0.110 & 0.107 & 0.530 & 0.025 & 0.080 \\
\hline
\end{tabular}

Type 1 households prefer the elimination of the PAYG system entirely. In 
particular, they prefer elimination over partial privatization, with or without mandatory annuitization. There are at least two reasons for their preference. First, these households have no fathers who would generate the demand for annuity insurance, and since these households are very young they would rather not be subject to forced saving. Second, they might be facing binding liquidity constraints and mandatory saving would then reduce their welfare. Another way to get the same intuition is to compare their lifetime welfare under the two PSA reforms. They prefer the one without annuitization for the same reasons listed above. In addition, type 1 households prefer the PSA reform to the PAYG benchmark.

For type 3 households, the proposed PSA reform benefits those with low preference for annuity insurance. In particular, the households with low life expectancy fathers (LL and LH households) are better off, where as households with long life expectancy fathers (HH and HL households) are worse off, relative to the benchmark PAYG social security system.

A great majority of type 3 households prefer to be born into the steadystate labeled 'PSA+Annuity' where there is mandatory saving at the $5 \%$ rate and wealth generated by this partial privatization program is annuitized at retirement. ${ }^{9}$ This finding might seem surprising since our households care

\footnotetext{
${ }^{9}$ Storesletten, Telmer, and Yaron (1999) also find annuitization welfare enhancing in their study of various social security reforms in a pure life cycle setting.
} 
about leaving bequests to their relatives. However, since fathers are alive in these households, they like to hold annuities and therefore mandatory annuitization does not lower their welfare. Moreover, the fathers are very close to retirement age and the timing of annuitization is also in line with the households' desire to hold annuities to insure the soon-to-be retirees. The HL households prefer the PAYG system. These households benefit from the progressivity of the PAYG system because of the low ability son, and the and they also receive a generous pension for the high ability father.

The proposed PSA reform benefits LH and LL type households and hurts $\mathrm{HH}$ and HL type households, relative to the benchmark equilibrium. This may be due to the fact that PSA does not provide annuity insurance against lifespan uncertainty while PAYG social security does so in the benchmark equilibrium. In fact, under PSA and mandatory annuitization, all ability types but HL enjoy higher lifetime welfare than in the benchmark economy.

To see how type 1 households feel about the proposed reforms, Table 4 calculates the rate of return to 'social security' for $\mathrm{H}$ and L types. ${ }^{10}$

\footnotetext{
${ }^{10}$ With 'social security' we mean the sum of the PAYG payroll tax and the mandatory saving rate. See the Appendix for the computation of the overall rate of return on social security.
} 
Table 4: Return of 'Social Security' for Type 1 HHs

\begin{tabular}{ccc}
\hline \hline & $\mathbf{H}$ & $\mathbf{L}$ \\
Benchmark & 2.70 & 2.90 \\
PSA+Annuity & 5.51 & 5.49 \\
PSA & 5.10 & 5.41 \\
\hline \hline
\end{tabular}

In both steady-states with PSAs, the expected return on social security at birth is higher than the after tax return on capital. In the case of PSA without annuitization, there is some progressivity in the benefits since there is a first-tier which is a flat benefit for every retiree. Indeed, the expected return of social security is higher for individuals with low ability (5.41\%) than for the $\mathrm{H}$ types $(5.10 \%)$. This difference between the returns for low and high ability households disappears when part of the retirement wealth is annuitized. In this case, high ability households enjoy a higher rate of return $(5.51 \%)$ than low ability households (5.49\%) because $\mathrm{H}$ types have a longer life expectancy than L types. Therefore, when the part of wealth generated by mandatory saving is annuitized at retirement, a rationale for introducing a flat first tier pension is to compensate low ability individuals for the fact that their expected life is shorter. 


\section{Conclusions}

The current debate on social security reform in the U.S. has focused on the relative merits of the existing PAYG system versus some form of partial privatization with a safety net for low income workers. In its key features, the 2001 Commission's proposals are similar to the reform recommendations made by the 1997 Advisory Council on Social Security, according to which there were three approaches formulated to solve the long-term financial imbalance in the program:

- Maintain Benefits: keep them essentially as is, but tax them.

- Individual Accounts: an additional and mandatory contribution of $1.6 \%$ of payroll.

- Personal Security Accounts: Convert the current system to a basic, flat benefit program, and $5 \%$ of the existing payroll tax redirected to PSAs.

There is serious discussion to change the current PAYG defined benefits program administered publicly into a two-tiered program with a first-tier flat basic pension financed in a PAYG manner, plus a privately managed defined contribution program. In the current defined benefit system, individuals are given insurance against life span risk as they receive retirement 
benefits as long as they are alive. On the other hand, a switch to a defined contribution retirement program can be designed to provide the same insurance if the funds in the individuals' accounts are required to be annuitized. However, as Diamond (1998) points out, political feasibility necessitates that the accounts' of the deceased be transferred to their estates. Diamond (1998) argues that mandatory annuitization may not be the best option on how funds are withdrawn during retirement if individuals care about leaving bequests to their descendents. Regulation about how to withdraw funds during retirement is also not a trivial issue if the individuals face binding borrowing constraints. Clearly, establishing such rules are an integral part of the design mechanism for reforming social security.

In this paper, we quantitatively evaluate the welfare effects of reforming social security by introducing a PSA with and without mandatory annuitization in an economic environment with bequests and borrowing constraints. Our setup allows us to assess whether mandatory saving or mandatory annuitization of accumulated PSA wealth at retirement is welfare enhancing, and if so, for what type of individuals.

Our setup is a two-sided altruistic framework where social security provides insurance against individual income and lifespan uncertainty. The economy is populated by overlapping generations of individuals that differ 
in income and lifetime expectancy. Following Laitner (1992), we specify preferences so that individuals derive utility from their own lifetime consumption and from the felicity of their predecessors and descendents. In this framework, an unfunded social security system competes with family insurance to insure households members for the two types of risk mentioned above. The family insurance takes the form of intervivos transfers and bequests. Overall, the economy consists of a rich set of households.

This framework is well suited to consider the annuity role of social security for single individuals versus for households where families also provide annuity insurance to their members. Our goal is to quantitatively evaluate the proposed reforms along the lines of PSAs with or without mandatory annuitization of PSA wealth at retirement in this setup where some households have higher desire to annuitize wealth than others. We calibrate our economy to the U.S. economy, use numerical, discrete state-space methods to solve the households recursive decision problem, and restrict attention on steady-states under various pension system.

Our main findings can be summarized as follows:

- A majority of households prefer a PSA reform (with or without mandatory annuitization) over the current PAYG pension system. Aggregate capital, output, and consumption, as well as individuals' lifetime wel- 
fare, are higher in the reformed pension system.

- Mandatory annuitization benefits most households.

In light of these findings, structuring the social security reform along a two-tiered system with a safety net for low income households, and allowing all households to accumulate retirement wealth faster through PSAs, and finally, requiring some level of annuitization of this wealth appear welfare improving for most households. 


\section{References}

[1] Advisory Council on Social Security (1996), "Report of the 1994-1996 Advisory Council on Social Security", in http://www.ssa.gov/policy/adcouncil/report/toc.htm.

[2] Boskin, Michael (1986), Too Many Promises: The Uncertain Future of Social Security, New York: Dow-Jones-Irwin Publishers.

[3] Diamond, Peter (1998), 'The Economics of Social Security Reform', NBER Working Paper No. 6719.

[4] Fuster, Luisa (1999), 'Is Altruism Important for Understanding the Long-Run Effects of Social Security?', Review of Economic Dynamics 2, No. 3, 616-637, (1999).

[5] Fuster, Luisa, Ayşe İmrohoroğlu, and Selahattin İmrohoroğlu (2003), 'A Welfare Analysis of Social Security in a Dynastic Framework,' International Economic Review, 1247-1274.

[6] Huggett, Mark, and Gustavo Ventura (1999), 'On the Distributional Effects of Social Security Reform', Review of Economic Dynamics, Vol. $2(3), 498-531$. 
[7] İmrohoroğlu, Ayşe, Selahattin İmrohoroğlu, and Douglas Joines (1998), 'The Effect of Tax-Favored Retirement Accounts on Capital Accumulation,' American Economic Review, September 1998, 88(4): 749-768.

[8] Laitner, John (1992), 'Random Earnings Differences, Lifetime Liquidity Constraints, and Altruistic Intergenerational Transfers,' Journal of Economic Theory 58,135-170, (1992).

[9] Storesletten, Kjetil, Chris Telmer, and Amir Yaron (1999), 'The RiskSharing Implications of Alternative Social Security Arrangements', Carnegie-Rochester Conference Series on Public Policy, Vol. 50, 213260. 


\section{Appendix}

This transition probability matrix is a function of the age of the house-

hold and of the abilities of the father and the son, and is given by

$$
\left[\chi_{j}\left(h, h^{\prime} ; z, z^{\prime}\right)\right]_{h, h^{\prime} \in\{1,2,3\}}=\left[\begin{array}{ccc}
\psi_{j}\left(z^{\prime}\right) & 0 & 0 \\
0 & \psi_{j+T}(z) & 0 \\
\psi_{j}\left(z^{\prime}\right)\left(1-\psi_{j+T}(z)\right) & \left(1-\psi_{j}\left(z^{\prime}\right)\right) \psi_{j+T}(z) & \psi_{j}\left(z^{\prime}\right) \psi_{j+T}(z)
\end{array}\right] .
$$




\title{
CESifo Working Paper Series
}

\author{
(for full list see www.cesifo.de)
}

1342 Johannes Becker and Clemens Fuest, A Backward Looking Measure of the Effective Marginal Tax Burden on Investment, November 2004

1343 Heikki Kauppi, Erkki Koskela and Rune Stenbacka, Equilibrium Unemployment and Capital Intensity Under Product and Labor Market Imperfections, November 2004

1344 Helge Berger and Till Müller, How Should Large and Small Countries Be Represented in a Currency Union?, November 2004

1345 Bruno Jullien, Two-Sided Markets and Electronic Intermediaries, November 2004

1346 Wolfgang Eggert and Martin Kolmar, Contests with Size Effects, December 2004

1347 Stefan Napel and Mika Widgrén, The Inter-Institutional Distribution of Power in EU Codecision, December 2004

1348 Yin-Wong Cheung and Ulf G. Erlandsson, Exchange Rates and Markov Switching Dynamics, December 2004

1349 Hartmut Egger and Peter Egger, Outsourcing and Trade in a Spatial World, December 2004

1350 Paul Belleflamme and Pierre M. Picard, Piracy and Competition, December 2004

1351 Jon Strand, Public-Good Valuation and Intrafamily Allocation, December 2004

1352 Michael Berlemann, Marcus Dittrich and Gunther Markwardt, The Value of NonBinding Announcements in Public Goods Experiments: Some Theory and Experimental Evidence, December 2004

1353 Camille Cornand and Frank Heinemann, Optimal Degree of Public Information Dissemination, December 2004

1354 Matteo Governatori and Sylvester Eijffinger, Fiscal and Monetary Interaction: The Role of Asymmetries of the Stability and Growth Pact in EMU, December 2004

1355 Fred Ramb and Alfons J. Weichenrieder, Taxes and the Financial Structure of German Inward FDI, December 2004

1356 José Luis Moraga-González and Jean-Marie Viaene, Dumping in Developing and Transition Economies, December 2004

1357 Peter Friedrich, Anita Kaltschütz and Chang Woon Nam, Significance and Determination of Fees for Municipal Finance, December 2004 
1358 M. Hashem Pesaran and Paolo Zaffaroni, Model Averaging and Value-at-Risk Based Evaluation of Large Multi Asset Volatility Models for Risk Management, December 2004

1359 Fwu-Ranq Chang, Optimal Growth and Impatience: A Phase Diagram Analysis, December 2004

1360 Elise S. Brezis and François Crouzet, The Role of Higher Education Institutions: Recruitment of Elites and Economic Growth, December 2004

1361 B. Gabriela Mundaca and Jon Strand, A Risk Allocation Approach to Optimal Exchange Rate Policy, December 2004

1362 Christa Hainz, Quality of Institutions, Credit Markets and Bankruptcy, December 2004

1363 Jerome L. Stein, Optimal Debt and Equilibrium Exchange Rates in a Stochastic Environment: an Overview, December 2004

1364 Frank Heinemann, Rosemarie Nagel and Peter Ockenfels, Measuring Strategic Uncertainty in Coordination Games, December 2004

1365 José Luis Moraga-González and Jean-Marie Viaene, Anti-Dumping, Intra-Industry Trade and Quality Reversals, December 2004

1366 Harry Grubert, Tax Credits, Source Rules, Trade and Electronic Commerce: Behavioral Margins and the Design of International Tax Systems, December 2004

1367 Hans-Werner Sinn, EU Enlargement, Migration and the New Constitution, December 2004

1368 Josef Falkinger, Noncooperative Support of Public Norm Enforcement in Large Societies, December 2004

1369 Panu Poutvaara, Public Education in an Integrated Europe: Studying to Migrate and Teaching to Stay?, December 2004

1370 András Simonovits, Designing Benefit Rules for Flexible Retirement with or without Redistribution, December 2004

1371 Antonis Adam, Macroeconomic Effects of Social Security Privatization in a Small Unionized Economy, December 2004

1372 Andrew Hughes Hallett, Post-Thatcher Fiscal Strategies in the U.K.: An Interpretation, December 2004

1373 Hendrik Hakenes and Martin Peitz, Umbrella Branding and the Provision of Quality, December 2004 
1374 Sascha O. Becker, Karolina Ekholm, Robert Jäckle and Marc-Andreas Mündler, Location Choice and Employment Decisions: A Comparison of German and Swedish Multinationals, January 2005

1375 Christian Gollier, The Consumption-Based Determinants of the Term Structure of Discount Rates, January 2005

1376 Giovanni Di Bartolomeo, Jacob Engwerda, Joseph Plasmans, Bas van Aarle and Tomasz Michalak, Macroeconomic Stabilization Policies in the EMU: Spillovers, Asymmetries, and Institutions, January 2005

1377 Luis H. R. Alvarez and Erkki Koskela, Progressive Taxation and Irreversible Investment under Uncertainty, January 2005

1378 Theodore C. Bergstrom and John L. Hartman, Demographics and the Political Sustainability of Pay-as-you-go Social Security, January 2005

1379 Bruno S. Frey and Margit Osterloh, Yes, Managers Should Be Paid Like Bureaucrats, January 2005

1380 Oliver Hülsewig, Eric Mayer and Timo Wollmershäuser, Bank Loan Supply and Monetary Policy Transmission in Germany: An Assessment Based on Matching Impulse Responses, January 2005

1381 Alessandro Balestrino and Umberto Galmarini, On the Redistributive Properties of Presumptive Taxation, January 2005

1382 Christian Gollier, Optimal Illusions and Decisions under Risk, January 2005

1383 Daniel Mejía and Marc St-Pierre, Unequal Opportunities and Human Capital Formation, January 2005

1384 Luis H. R. Alvarez and Erkki Koskela, Optimal Harvesting under Resource Stock and Price Uncertainty, January 2005

1385 Ruslan Lukach, Peter M. Kort and Joseph Plasmans, Optimal R\&D Investment Strategies with Quantity Competition under the Threat of Superior Entry, January 2005

1386 Alfred Greiner, Uwe Koeller and Willi Semmler, Testing Sustainability of German Fiscal Policy. Evidence for the Period 1960 - 2003, January 2005

1387 Gebhard Kirchgässner and Tobias Schulz, Expected Closeness or Mobilisation: Why Do Voters Go to the Polls? Empirical Results for Switzerland, 1981 - 1999, January 2005

1388 Emanuele Bacchiocchi and Alessandro Missale, Managing Debt Stability, January 2005

1389 Assar Lindbeck and Dirk Niepelt, Improving the SGP: Taxes and Delegation rather than Fines, January 2005 
1390 James J. Heckman and Dimitriy V. Masterov, Skill Policies for Scotland, January 2005

1391 Emma Galli \& Fabio Padovano, Sustainability and Determinants of Italian Public Deficits before and after Maastricht, January 2005

1392 Angel de la Fuente and Juan Francisco Jimeno, The Private and Fiscal Returns to Schooling and the Effect of Public Policies on Private Incentives to Invest in Education: A General Framework and Some Results for the EU, January 2005

1393 Juan C. Conesa and Carlos Garriga, Optimal Response to a Demographic Shock, January 2005

1394 Christian Gollier, Optimal Portfolio Management for Individual Pension Plans, February 2005

1395 Ruslan Lukach, Joseph Plasmans and Peter M. Kort, Innovation Strategies in a Competitive Dynamic Setting, February 2005

1396 Gebhard Kirchgässner, (Why) Are Economists Different?, February 2005

1397 Marko Köthenbürger, Panu Poutvaara and Paola Profeta, Why are More Redistributive Social Security Systems Smaller? A Median Voter Approach, February 2005

1398 Gabrielle Demange, Free Choice of Unfunded Systems: A First Assessment, February 2005

1399 Carlos Fonseca Marinheiro, Sustainability of Portuguese Fiscal Policy in Historical Perspective, February 2005

1400 Roel M. W. J. Beetsma and Koen Vermeylen, The Effect of Monetary Unification on Public Debt and its Real Return, February 2005

1401 Frank Asche, Petter Osmundsen and Maria Sandsmark, Is It All Oil?, February 2005

1402 Giacomo Corneo, Media Capture in a Democracy: The Role of Wealth Concentration, February 2005

1403 A. Lans Bovenberg and Thijs Knaap, Ageing, Funded Pensions and the Dutch Economy, February 2005

1404 Thiess Büttner, The Incentive Effect of Fiscal Equalization Transfers on Tax Policy, February 2005

1405 Luisa Fuster, Ayşe İmrohoroğlu and Selahattin İmrohoroğlu, Personal Security Accounts and Mandatory Annuitization in a Dynastic Framework, February 2005 